\title{
Anxiety and depression levels among multidisciplinary health residents*
}

\author{
Níveis de ansiedade e depressão entre residentes multiprofissionais em saúde
}

Daniela Salvagni Rotta ${ }^{1}$, Maria Helena Pinto ${ }^{1}$, Luciano Garcia Lourenção ${ }^{1}$, Priscila Regina Teixeira ${ }^{1}$, Elizangela Gianini Gonsalez ${ }^{1}$, Claudia Eli Gazetta ${ }^{1}$

Objective: to assess symptoms of anxiety and depression of professionals of Multidisciplinary Health Residence Programs. Methods: this is a cross-sectional study, performed with fifty professionals, using three instruments: one for socioeconomic and demographic data, and the Beck's Anxiety and Depression Scale. Results: predominance of females (92.0\%), average age 26 years old, single (88.0\%), family income from two to five salaries $(56.0 \%)$ satisfied with the work (82.0\%) and thought about quitting the program $(56.0 \%)$ showed anxiety (50.0\%) and depression (28.0\%). Conclusion: there was an association between anxiety and depression in multidisciplinary residents, which points to the need for rethinking strategies for identifying these symptoms and control of stress factors for the promotion of mental health.

Descriptors: Health Personnel; Internship and Residency; Anxiety; Depression.

Objetivo: avaliar sintomas de ansiedade e depressão dos profissionais dos Programas de Residência Multiprofissional em Saúde. Métodos: estudo transversal, com cinquenta profissionais, utilizando-se três instrumentos: um para dados socioeconômicos e demográficos, e as Escalas de Ansiedade e Depressão de Beck. Resultados: predominância do sexo feminino (92,0\%), idade média 26 anos, solteiros (88,0\%), renda familiar de dois a cinco salários (56,0\%), satisfeitos com o trabalho $(82,0 \%)$ e pensaram em desistir do programa (56,0\%), apresentaram ansiedade (50,0\%) e depressão (28,0\%). Conclusão: observou-se associação entre ansiedade e depressão em residentes multiprofissionais, o que aponta a necessidade de repensar estratégias de identificação destes sintomas e controle dos fatores estressores para a promoção da saúde mental.

Descritores: Pessoal de Saúde; Internato e Residência; Ansiedade; Depressão.

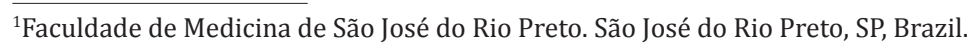

Corresponding author: Maria Helena Pinto

Rua Benjamin Constant, 3388 - Apto 121. CEP: 15015-600. São José do Rio Preto, SP, Brazil. E-mail: mariahelena@famerp.br 


\section{Introduction}

The Multidisciplinary Health Residence Programs were created in 2005 by the Law no. 11,129, to enable graduates to develop professional attitudes, becoming good professionals and responsible, and acquiring knowledge and skills in daily work, with the opportunity to exercise the knowledge acquired during undergraduate ${ }^{(1)}$. It is a post-graduation modality lato sensu characterized by in-service training under supervision, full-time and is as an effective way of development and specialization in health care, and enable integration between education, service and community, promoting partnerships among managers, workers and users, aiming a collective training in service and staff, which can contribute to the care of the user integrity ${ }^{(2-3)}$. Thus, this program allows the exchange of knowledge among the various specialties and between scientific knowledge and popular knowledge because the professional is inserted into the service in contact with users and communities, integrating theory and practice ${ }^{(1)}$.

With the admission into the residence program, changes occur in the professional and individual life of the individual. Many move to other cities to attend the program, separate from families and friends and need a fast adaption to the new reality. Several suffer from anxieties, tensions of lifestyle change and the working environment and fail to create effective strategies for dealing with such situations, bringing negative consequences, such as dissatisfaction and high risk for the development of anxiety and depression ${ }^{(4)}$.

The analysis of the scientific literature about the formation process in the context of residence, mainly in specialties, shows that professionals are affected by high rates of health problems that interfere with their quality of life and, consequently, the care service user $^{(5)}$.

Residents may feel incompetent and worthless being unfamiliar with the demand of patients and responsibilities, facing a constant internal pressure, which can contribute to their maturity or be an environmental factor triggering disorders ${ }^{(6)}$, such as anxiety, which tends to be common among health professionals $^{(7)}$.

Considering the changes in daily life and stress faced by the professional during the graduate process in the Multidisciplinary Health Residence, this study aimed to assess symptoms of anxiety and depression of professionals of Multidisciplinary Health Residence Programs.

\section{Methods}

This is a cross-sectional study, populationbased, conducted among professionals enrolled in the Multidisciplinary Health Residence Programs of an educational institution in the interior of São Paulo, Brazil state in 2013, who agreed to participate in the research after informed about the objectives and research purpose, totaling fifty professionals from different areas. They excluded those who were distant from the professional activities for any reason during the period of data collection.

The data collection was performed with three self-report instruments: one instrument developed by the authors containing personal data such as age, gender, marital status, professional category, family income, and if they are satisfied or thought about quitting the program; Beck Anxiety Scale or Beck Anxiety Inventory measures the severity of the individual's anxiety symptoms, from 21 questions about how they felt last week, expressed as a common anxiety symptoms with four possible answers (absence, lightly, moderately, severely) ${ }^{(8)}$, and the Beck Depression Scale and the Beck Depression Inventory, also composed of 21 questions that address items related to depressive symptoms such as hopelessness, irritability and cognitions, guilt or feelings of being punished, physical symptoms such as fatigue, weight loss and decreased libido ${ }^{(9)}$.

Demographic and socioeconomic data characterized the study population. Depression anxiety levels were analyzed by a psychologist, 
according to instruments data and categorized in the absence of depression/anxiety, depression/ light anxiety, depression/moderate anxiety, and depression/serious anxiety.

The data analysis was performed using Statistical Package for Social Sciences program, version 17.0. Comparisons were made by Kappa agreement test, considered significant $\mathrm{p}$-value less than or equal to 0.05 .

The study complied with the formal requirements contained in the national and international standards, regulatory of research involving human beings.

\section{Results}

Fifty professionals from different categories, most nurses participated in the study (30.0\%).

As shown in Table 1, the prevalence of female was observed; aged between 21 and 35 years old, with an average of 24.5 years old (SD \pm 2.6 years) and CI $95 \%$ from 23.8 to 25.3 years old; singles and family income between two and five minimum wages.

It is noteworthy that most of the professionals reported being satisfied with the program in which they were registered, although about half of them had ever thought about quitting the course (Table 1).

Residents showed symptoms of anxiety associated or not with depression (50.0\%); as well as the relationship between anxiety and depression. There is reasonable agreement among professionals with the absence of anxiety and depression $(\mathrm{K}=0.240)$; there is no agreement between professionals with anxiety and light depression ( $\mathrm{K}=-0.122)$ and/or moderate ( $\mathrm{K}=-0.133)$; medium agreement $(\mathrm{K}=0.240)$ between professionals with severe anxiety and depression $(\mathrm{K}=0.485)$ and in the overall analysis, there was a low correlation between anxiety and depression $(\mathrm{K}=0.072$ ). There was statistically significant in the correlation between professionals with severe anxiety and depression $(\mathrm{p}<0.001)$.
Table 1 - Distribution of socio-demographic and satisfaction characteristics of professionals enrolled in the Multidisciplinary Residence Program

\begin{tabular}{lccccc}
\hline \multirow{2}{*}{ Variables } & \multicolumn{3}{c}{$\begin{array}{c}\text { Satisfied with the } \\
\text { program }\end{array}$} & $\begin{array}{c}\text { Thought about } \\
\text { quitting }\end{array}$ \\
\cline { 3 - 6 } & & Yes & No & Yes & No \\
& $\mathbf{n}(\%)$ & $\mathbf{n}(\%)$ & $\mathbf{n}(\%)$ & $\mathbf{n}(\%)$ & $\mathbf{n ( \% )}$ \\
\hline
\end{tabular}

Professional category

Nursing

$15(30.0) \quad 12(29.3) \quad 3(33.3) 10(35.7) \quad 5(22.7)$

Nutrition

$9(18.0) \quad 8(19.5) \quad 1(11.1) \quad 3(10.7) \quad 6(27.3)$

Occupational Therapy

Physiotherapy

Psychology

$7(14.0) \quad 3(7.3) \quad 4(44.4) \quad 7(25.0)$

Speech Therapy

$5(10.0) \quad 5(12.2)$

1 (3.6) $4(18.2)$

Speech Therapy

$4(8.0)$

$3(7.3) \quad 1(11.1) \quad 2(7.1) \quad 2(9.1)$

Biological Sciences

$3(6.0) \quad 3(7.3)$

$2(7.1) \quad 1(4.5)$

Pharmacy

$2(4.0) \quad 2(4.9)$

$2(9.1)$

Odontology

$2(4.0) \quad 2(4.9)$

$1(3.6) \quad 1(4.5)$

Veterinary Medicine

$2(4.0) \quad 2(4.9)$

2 (7.1)

$1(2.0) \quad 1(2.4)$

$1(4.5)$

Gender

Female

Male

Age group (years)

$20-25$

$26-30$

Minimum age

Maximum age

Middle age

$46(92.0) 37(90.2) 9(100.0) 27$ (96.4) 19 (86.4)

$4(8.0) \quad 4(9.8)$

$1(3.6) \quad 3(13.6)$

Marital status

Single

Married

Other

$38(76.0) \quad 31(75.6) \quad 7(77.8) 22(78.6) 16(72.7)$

$10(20.0) \quad 10(24.4) 2(22.2) \quad 6(21.4) \quad 6(27.3)$

$\begin{array}{ccccc}21 & 21 & 22 & 21 & 23 \\ 35 & 33 & 35 & 35 & 29 \\ & & & & \\ 24.5 & 24.6 & 24,0 & 24.1 & 24.6 \\ (S D: \pm 2.6) & (S D: \pm 2.6) & (S D: \pm 2.6) & (S D: \pm 2.6) & (S D: \pm 2.6)\end{array}$

Family income*

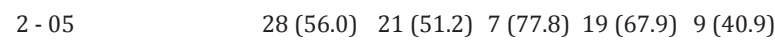

$6-10$

$13(26.0) \quad 12(29.3) \quad 1(11.1) \quad 6(21.4) \quad 7(31.8)$

$>10$

$9(18.0) \quad 8(19.5) \quad 1(11.1) \quad 3(10.7) \quad 6(27.3)$

*Minimum Wage Value: $\mathrm{R} \$ 744,00$ 
Table 2 - Relationship between anxiety and depression for professionals enrolled in the Multidisciplinary Health Residence Program

\begin{tabular}{|c|c|c|c|c|c|}
\hline \multirow[b]{2}{*}{ Variables } & \multicolumn{4}{|c|}{ Depression } & \multirow[b]{2}{*}{ Total } \\
\hline & $\begin{array}{c}\text { Absence } \\
\text { n (\%) }\end{array}$ & $\begin{array}{l}\text { Light } \\
\text { n (\%) }\end{array}$ & $\begin{array}{c}\text { Moderate } \\
\text { n (\%) }\end{array}$ & $\begin{array}{c}\text { Serious } \\
\text { n (\%) }\end{array}$ & \\
\hline \multicolumn{6}{|l|}{ Anxiety } \\
\hline Absence & $21(42.0)$ & $3(6.0)$ & $1(1.0)$ & - & $25(50.0)$ \\
\hline Light & $9(18.0)$ & $1(2.0)$ & $1(2.0)$ & - & $11(22.0)$ \\
\hline Moderate & $6(12.0)$ & $5(10.0)$ & - & - & $11(22.0)$ \\
\hline Serious & - & - & $2(4.0)$ & $1(2.0)$ & $3(6.0)$ \\
\hline Total & $36(72.0)$ & $9(18.0)$ & $4(8.0)$ & $1(2.0)$ & $50(100.0)$ \\
\hline Kappa & 0.240 & -0.122 & -0.133 & 0.485 & 0.072 \\
\hline$P$ value & 0.059 & $*$ & $*$ & $<0.001$ & 0.420 \\
\hline CI 95\% & \multicolumn{5}{|c|}{$-0.009-0.489-0.397-0.153-0.368-0.1020 .247-0.722-0.102-0.245$} \\
\hline
\end{tabular}

\section{Discussion}

The female prevalence in this study was also demonstrated in a University Hospital in Spain, where $38.5 \%$ of the sample was composed of nurses ${ }^{(5)}$. Similar results were observed among students in the health field, the University of Santa Catarina and the University of Pakistan, where about $72.0 \%$ of the students were female ${ }^{(10-11)}$. The differential by gender observed in studies with female prevalence is related to the structure of health teams, composed predominantly by nursing that is historically characterized by a predominance of females ${ }^{(12-13)}$.

The age group observed in this study is consistent with results between residents of the Federal University of Rio Grande do Sul, which showed $51.3 \%$ of professionals between the ages of 25 and 29 years old ${ }^{(13)}$, and the Federal University of Pernambuco, whose professionals average age was 27 years old ${ }^{(12)}$.

Regarding marital status, the Federal University of Pernambuco and the Federal University of Santa Maria showed percentages of single professionals lower than those observed in this study $(74.0 \%$ and $81.1 \%$, respectively $)^{(12,14)}$. It is assumed that the prevalence of singles among the studied professionals is related to age group because they are young professionals and recent graduates.

A study with professionals in a university hospital analyzed the influence of gender and age with job satisfaction and showed that younger and women declared more satisfied. They concluded that the desire to learn and gain experience could make young people evaluate positive aspects of the work ${ }^{(15)}$.

Anxiety and depression levels among residents are similar to those observed in a study of health trainees in Malaysia, which showed anxious participants (60.7\%), slightly anxious (13.5\%), moderately anxious (28.1\%) and extremely anxious $(15.7 \%)^{(2)}$. There was the prevalence of female workers $(60.6 \%)$, single $(80.8 \%)$ with a mean age of 26.1 years old ${ }^{(2)}$.

On the other hand, a Pakistani study performed with medical students showed lower symptoms of anxiety and depression ${ }^{(11)}$, showing that the student-medical transition is an exhausting process for professionals, as corroborates a study by the University of Toronto, identifying the anxiety levels at the beginning of the first year were higher than at the end of the course, when trust and familiarity with the work routine have already established ${ }^{(7)}$.

The pressure related to the elaboration of reports, poor relationships with colleagues and superiors are among the factors that cause anxiety ${ }^{(2)}$. In Norway, exploring personality traits among professional trainees associated with symptoms of anxiety, depression and work stress reports during training/internship pointed out that the perception of stress at work was positively correlated with the levels of anxiety and depression, being the levels of symptoms of anxiety higher than depression. It was also noted that the female trainees experienced greater work stress levels than men ${ }^{(16)}$.

There are evidences that working and routine environment are the main factors that contribute to the levels of anxiety and depression $(50.0 \%$ and $28.0 \%$, respectively), as the workload of the 
Multidisciplinary Health Residence programs is 60 hours per week, lasting 24 months, a period in which professionals develop theoretical and practical activities. It is understood also that this step of the training process is one of the most stressful stages because the recent graduate, young and inexperienced, is exposed to stressful situations, such as the conflict between professionals from different graduations, different specialties, relationship with family and clients with serious illness, fear of contamination, job insecurity, imbalance of professional expectations, job complexity, in addition to the rotation in various sectors and institutions ${ }^{(6)}$.

It is also noted that anxiety is typical of every profession, and therefore, the evaluation of the stressor and the way of coping or adaptation to the stressor are individual, depending on the work process and teaching-learning that accompanies the existential process. The stress may be associated with the administration of professional responsibility, patient treatment, management of problematic situations, managing the volume of knowledge, establishing the limits of their personal and professional identity, teamwork, interpersonal relationships and responsibility of employing an integral and humanized care $^{(14)}$.

The results of this study can contribute to reflections about working conditions and the process of multidisciplinary health residents, which can be factors predisposing to anxiety and depression. The main limitation was the lack of publications on the subject, emphasizing the need for expansion of scientific research with multidisciplinary health residents. To make this assessment more effective, further studies are needed, with questions related to factors related to other contexts, such as the causes of dissatisfaction and the reasons that lead professionals to think about quitting the program. Another limitation was the study performance in just one training center, limiting the analysis of the results.

\section{Conclusion}

Most residents of this study were women, young, single, with family income between two to five minimum wage and that although satisfied with the program, had been thinking about quitting. The study showed an association between anxiety and depression, suggesting the need for greater attention to professionals as well as the implementation of actions aimed at the welfare of this population, with early identification of symptoms of anxiety and stress, control of stress factors and mental health promotion, avoiding the social impacts caused by these disorders, as well as the individual disability.

\section{Acknowledgements}

To the Medicine Faculty of São José do Rio Preto for funding this study, through the Scholarship Program of Research Assistance 2013/2014.

\section{Collaborations}

Rotta DS contributed to the project design, analysis and interpretation of data and writing of the article. Pinto MH and Lourenção LG contributed to the writing of the article, relevant critical review of the intellectual content and final approval of the version to be published. Texeira PR, Gonsalez EG and Gazetta EC contributed to the analysis and interpretation of data, and with the relevant critical review of the intellectual content.

\section{References}

1. Tan SMK, Jong SC, Chan LF, Jamaludin NA, Phang CK, Jamaluddin NS, etal. Physician, heal thyself: the paradoxe of anxiety amongst house officers and work in a teaching hospital. Asia Pac Psychiatry. 2013; 5(suppl):74-81. 
2. Batista NA. Interprofessional education in health: concepts and practices. Cad FNEPAS [Internet]. 2012 [cited 2015 Dec 02]; 2:25-8. Available from: http://www.sbfa.org.br/fnepas/v1_ingles/ artigo\%2011\%20-\%20interprofissional.pdf

3. Miranda Neto MV, Leonello VM, Oliveira MAC. Residências multiprofissionais em saúde: análise documental de projetos político-pedagógicos. Rev Bras Enferm. 2015; 68(4):586-93.

4. Hope V, Henderson M. Medical student depression, anxiety and distress outside North America: a systematic review. Med Educ. 2014; 48(10):96379.

5. Lourenção LG, Moscardini AC, Soler ZASG. Saúde e Qualidade de Vida de Médicos Residentes. Rev Assoc Med Bras. 2010; 56(1):81-91.

6. Franco GP, Barros ALBL, Nogueira-Martins LA, Zeitoun SS. Burnout en residentes de enfermería. Rev Esc Enferm USP. 2011; 45(1):12-8.

7. Hurst C, Kahan D, Ruetalo M, Edwards S. A year in transition: a qualitative study examining the trajectory of first year residents' well-being. BMC Med Educ [Internet]. 2013 [cited 2015 Feb 17]; 13:96. Available from: http://www. biomedcentral.com/1472-6920/13/96

8. Wang YP, Gorenstein C. Psychometric properties of the Beck Depression Inventory-II: a comprehensive review. Rev Bras Psiquiatr. 2013; 35(4):416-31.

9. Gomes-Oliveira MH, Gorenstein C, Lotufo Neto F, Andrade LH, Wang YP. Validation of the Brazilian Portuguese version of the Beck Depression Inventory-II in a community sample. Rev Bras Psiquiatr. 2012; 34(4):389-94.
10. Sakae TM, Padão DL, Jornada LK. Sintomas depressivos em estudantes da área da saúde em uma Universidade no sul de Santa Catarina UNISUL. Rev AMRIGS. 2010; 54(1):38-43.

11. Alvi T, Assad F, Ramzan M, Khan FA. Depression, anxiety and their associated factors among medical students. J Coll Physicians Surg Pak. 2010; 20(2):122-6.

12. Carvalho CN, Filho D, Carvalho AG, Amorim ACG. Prevalência e fatores associados aos transtornos mentais comuns em residentes médicos e da área multiprofissionais. J Bras Psiquiatr. 2013; 62(1):38-45.

13. Goulart CT, Silva RM, Bolzan MEO, Guido LA. Perfil sociodemográfico e acadêmico dos residentes multiprofissionais de uma universidade pública. Rev Rene. 2012; 13(1):178-86.

14. Guido LA, Goulart CT, Silva RM, Lopes LFD, Ferreira EM. Stress and Burnout among multidisciplinary residents. Rev Latino-Am Enfermagem. 2012; 20(6):1064-71.

15. Carrillo-García C, Solano-Ruíz MC, MartínezRoche ME, Gómez-García CI. Job satisfation among health care workers: the role of gener and age. Rev Latino-Am Enfermagem. 2013; 21(6):1314-20.

16. Gramstad TO, Gjestad R, Haver B. Personality traits predict job stress, depression and anxiety among junior physicians. BMC Med Educ [Internet]. 2013; [cited 2015 Dec 13]; 13:150. Available from: http://bmcmededuc.biomedcentral.com/ articles/10.1186/1472-6920-13-150 